\title{
SERAT JANGKA JAYABAYA RELASI SASTRA, SEJARAH DAN NASIONALISME
}

\author{
Gusti Garnis Sasmita \\ Pendidikan Sejarah Pascasarjana Universitas Sebelas Maret \\ gustigarnis@gmail.com \\ Hermanu Joebagio \\ Pendidikan Sejarah Pascasarjana Universitas Sebelas Maret \\ Sariyatun \\ Pendidikan Sejarah Pascasarjana Universitas Sebelas Maret
}

\begin{abstract}
Abstrak
Rendahnya minat sejarawan terhadap serat Jangka Jayabaya dipengaruhi oleh faktor konten mitologi dalam serat ini. Di sisi lain popularitas Jangka Jayabaya justru tinggi dikalangan masyarakat awam. Hal yang menarik dalam fokus penelitian ini yaitu mengkaji Serat Jangka Jayabaya berdasarkan sisi aksiologis, sisi ontologis, sisi epistemologis dan serta sumbang silihnya terhadap resistensi terhadap kolonialisme. Penelitian ini merupakan penelitian kualitatif historis dengan tehnik pengumpulan data studi literatur, observasi, wawancara dan kuisioner. Hasil penelitian menunjukkan bahwa popularitas Serat Jangka Jayabaya melalui proses panjang dalam sejarah Indonesia merupakan awal benih nasionalisme. Sastra yang ditinjau berdasarkan intertektual kepengarangan nyatanya dapat digunakan sumber sejarah primer terkait mentalitas mayarakat sezaman.
\end{abstract}

Kata kunci : Jangka Jayabaya, respon, perubahan sosial

\begin{abstract}
Lower interest historians of Serat Jangka Jayabaya caused by content of mythological stories. But in the other side, the higer popularity of Jangka Jayabaya found in the common people. The interest in this study is the focus of research that review Serat Jangka Jayabaya ontologically, epistemologically and axiologically and that contribute to the resistence of colonialism. This study uses qualitative histories methods with literature study, interviews and questionnaires. The results of research indicating that the Serat Jangka Jayabaya to date have reached a spate in the history of Indonesia as the beginning of nationalism. The literature reviewed through intertextual authorship is in fact history related to the mentality of contemporary society.
\end{abstract}

Keywords: Jayabaya term, response, social change.

\section{PENDAHULUAN}

Rendahnya minat sejarawan terhadap sumber sejarah berupa sastra seperti serat Jangka Jayabaya dilatarbelakangi salah satu faktor diantaranya ialah konten isi serat tersebut yang berupa cerita mitologi. Hal tersebut mengungkapkan bahwasanya sejarawan cenderung menilai bahwa sebagai sumber sejarah Jangka Jayabaya tidak memiliki relasi terhadap Kerajaan Kediri karena dianggap naskah tertua dan berbagai versi dari erat terebut justru ditemukan berasal dari kesultanan mataram jawa tengah. Hal ini ditinjau baik dalam kepengarangan maupun bahan serat yang memang sengaja diciptakan berdasarkan izin keraton. 
Namun yang menarik ialah bagaimana kemudian popularitas Jangka Jayabaya kembali diperbanyak oleh percetakan buku pertama yang berada di kediri Tan Koen Swi. Namun cetakan buku terebut kini menjadi hal yang langka diketemukan di Kediri. Tetapi kita justru akan mudah menemukannya di solo terutaman di salah satu toko buku bekas terbitan lama, yang banyak orang menyebutnya dengan istilah "Gladak". Selain itu berbagai veri Jangka Jayabaya yang kemudian justru berbeda dengan Serat Jangka Jayabaya justru semakin digandrungi oleh masyarakat luas. Hal ini merupakan sebuah pergeseran konten Serat Jangka Jayabaya sebagai versi Ranggawarsita dalam beberapa cetakan buku penerbit Tan Koen Swi. Dimungkinkan bahwa hal tersebut memang sengaja diperbanyak pada masanya dikarenakan konser Jangka Jayabaya sebagai kebebasan yang diimpikan oleh masyarakat yang menolak perubahan atau modernisasi. Nampaknya para penulis telah mampu menyerap sebuah budaya literasi sejak awal. Sebagaimana para pujangga Keraton selalu melakukan sitasi terhadap naskahnaskah yang mereka baca terbitan tahun sebelumnya. Maka konsep rekonstruksi serat Jangka Jayabaya telah mampu dilaksanakan oleh masyarakat pada awal abad 19. Hal inilah yang menjadi problematik terhadap persepsi sejarawan dalam menyikapi sumber sejarah yang terpecah dari berbagai versi.

Disisi lain popularitas Jangka Jayabaya justru tergolong tinggi dikalangan masyarakat awam, terutama pada masyarakat jawa secara umum dan masyarakat Kediri khususnya. Hal ini menunjukkan bahwa kepercayaan terhadap mitologi masih berakar kuat dalam mentalitas masyarakat Indonesia. Sebuah akulturasi dan sinkretisme kepercayaan nampaknya justru semakin subur di era rasionalitas globalisasi dewasa ini. Sebagai contoh di dalam masyarakat kediri ialah emakin ramainya upacara peringatan 1 Suro di Petilasan Sri Aji Jayabaya (Sasmita, 2017). Maka, kesimpulannya adalah bahwa budaya sejarah lisan nampaknya menjadi tempat penting di khalangan masyarakat umum. Popularitas Jangka Jayabaya juga dipengaruhi oleh berbagai kondisi sosial politik dalam suatu wilayah. Dibalik popularitas tersebut menuai banyak pro dan kontra. Namun benang merah dapat kita tarik terhadap dinamika Serat Jangka Jayabaya, yakni adanya relasi antara sastra, sejarah dan nasionalisme berupa eksistensi nilai lokal genius dalam resistensi melawan kolonialisme.

\section{METODE}

Penelitian ini merupakan menggunakan metode penelitian kualitatif historis yang mendapatkan informasi melalui studi literatur, observasi, wawancara dan 
kuisioner yang mengacu pada metodolofgi sejarah, dengan beberapa tahapan seperti pencarian sumber sejarah, kritik intern, kritik ekstern, interpretasi dan historiografi (Hidayat, 2016). Adapun obyek penelitian dalam studi literatur ialah Serat Jangka Jayabaya gubahan Ranggawarsita koleksi Museum Radyapustaka, dan Serat Jangka Jayabaya koleksi perpustakaan pusat UNS. Sedangkan obyek observasi dalam kuisioner berupa mahasiswa pendidikan sejarah UNS, sedangkan informan wawancara ialah anggota forum diskusi komunitas PASAK (Pelestari Sejarah Kediri) dalam sosial media facebook, penjaga arsip museum RadyaPustaka Bapak Totok Yasmiran, ahli sastra jawa R.Adi Deswijaya, S.S., M.Hum, ahli filsafat dr.R.Wisnu Kusumawardana, dan masyarakat kediri. Adapun dalam pengumpulan informasi dilaksanakan hingga didapatkan data yang bersifat jenuh atau mengerucut. Untuk memahami dinamika perubahan Serat Jangka Jayabaya perlu dikupas secara filsafat.

\section{HASIL DAN PEMBAHASAN}

Berdasarkan hasil penelitian ini didapatkan beberapa poin terhadap rumusan masalah Kajian ontologis, aksiologis dan epistemologis Serat Jangka Jayabaya yakni Nasionalisme agamis abad 18; Serat Jangka Jayabaya sebagai karya sastra abad 18; Serat Jangka
Jayabaya sebagai respon pujangga terhadap ketimpangan sosial; Diskurus Ratu adil sebagai resistensi masyarakat terhadap kolonialisme sebagai benih nasionalisme.

\section{Nasionalisme agamis abad $\mathbf{1 8}$}

Nasionalisme secara etimologis berasal dari 2 kata yakni, "nation" yang berarti negara dan "isme" yang berarti paham. Secara garis besar nasionalisme dapat dikatakan sebagai rasa kesetiaan untuk berjuang demi tanah air. Adapun ciri-ciri dari nasionalisme itu sendiri antara lain; (1) rasa cinta tanah air, (2) keinginan untuk merdeka (bebas dari segala bentuk penjajahan), (3) adanya rasa kesatuan dan persatuan. Berdasarkan sejarah tumbuh kembang nasionalisme di Indonesia diawali dengan berbagai konflik akibat kolonialisme bangsa asing di Indonesia. Adapun sebelum diikrarkannya sumpah pemuda, sebagai salah satu tombak simbol nasionalisme Indonesia, nyatanya nasionalisme mulai tumbuh dalam berbagai kelompok-kelompok melalui paham kepercayaan atau agama yang dipegang. Yang dalam hal ini dinamakan dengan nasionalisme agama. Dalam hal tersebut agama jawa memiliki peran penting dalam tumbuh kembang nasionalisme. Terutama sebuah kepercayaan terhadap perang suci dalam ideologi Ratu Adil. 
Rasa senasib sepenanggungan akibat ketidakadilan sistem kolonialisme, dikenalnya pendidikan formal, dan masuknya berbagai faham baru di Indonesia merupakan awal dari rasa kesatuan dan persatuan. Dikuasainya keraton mataram sebagai negara boneka pemerintah kolonial nampaknya mendorong adanya berbagai pergerakan diluar lingkup keraton yang dengan bebas dan lantang menyatakan resistensi terhadap kolonialisme. Kebebasan bergerak dan keleluasaan ini tidak hadir begitu saja tanpa ada campur tangan dari beberapa oknum intern keraton. Hal ini berdasarkan asumsi bahwa, setiap perilaku kolektif memerlukan figur pemimpin sebagai penggerak dan tujuan atau keyakinan bersama, selain dari pada kesenjangan struktural dan gejolak dalam suatu momentum peristiwa. Maka untuk menjadi seorang penggerak diperlukan adanya kemampuan yang cenderung hanya didapatkan oleh keluarga-keluarga bangsawan keraton. Kaum aristokrat protagonis yang terpinggir dalam ruang lingkup keraton cenderung melakukan koalisi dengan berbagai pihak guna menghasilkan simbiosis mutualisme dalam sebagai awal resistensi. Secara politik pemimpin dari kelas atas memiliki kekuasaan, kemampuan serta kekayaan sebagai faktor pergerakan masyarakat. Dalam menghimpun gerakan inilah terjadi suatu sistem nasionalisme agamis, yang mana terjadi sekularisme terhadap sebuah kepercayaan guna kepentingan pergerakan sosial. Hal ini dicerminkan dari bagaimana serat jangka jayabaya yang mengususng konsep ratu adil secara turun temurun dilestarikan oleh berbagai generasi baik dari dalam maupun luar lingkup keraton mataram islam. Semula serat jangka jayabaya yang berisikan sinkretisme paham islam dan agama kejawen telah berkembang sedemikian rupa menjadi salah satu bentuk protes sosial yang popularitasnya meningkat justru setelah dikenalnya karangankarangan Ranggawarsita beberapa tahun setelah sang penulis yang dikenal dengan pengangkatan istilah zaman edannya ini wafat. Hal tersebutlah kemudian yang dimanfaatkan oleh berbagai perjuangan abad 18 guna menghimpun masa. walaupun konsep ratu adil bukan satusatunya faktor penentu dalam keberhasilan melawan penjajahan, seperti dalam penelitian Wulan Sondarika yang menjelaskan pentingnyaa peranan wanita dalam perjuangan kemerdekaan indonesia masa pendudukan jepang (Sondarika, 2017) dan penelitian mengenai perjuangan pasca kemerdekaan karya Agus Susilo dengan judul sejarah perjuangan jenderal soedirman dalam mempertahankan Indonesia 1945-1950 (Susilo, 2018), upaya mendeskribsikan dinamika serat jangka Jayabaya dengan Ratu Adil sebagai ideologi pengabsahan 
pergerakan sosial merupakan salah satu bentuk pendidikan nilai dalam pembelajaran sejarah. Pembelajaran dengan penanaman nilai juga telah banyak dilakukan dalam pembelajaran sejarah salah satunya ialah pengembangan modul sejarah pergerakan indonesia terintegrasi nilai karakter religius Kuswono yang menanalisis kebutuhan dalam mengembangkan modul pembelajaran sejarah terintegrasi nilai karakter religius (Kuswono, 2017).

\section{Serat Jangka Jayabaya sebagai karya sastra abad 18}

Serat Jangka Jayabaya koleksi museum Radyapustaka dalam penelitian ini merupakan karya sastra keraton kasunanan Surakarta, berdasarkan tulisan tangan Padmasusastra sebagai naskah tedhak.an atau salinan. Secara harfiah "Jangka" dapat diartikan sebagai petunjuk, yang kemudian oleh masyarakat awam justru salah diartikan sebagai ramalan atau prediksi tentang masa depan. Sedangkan Jayabaya dapat dipisahkan menjadi 2 suku kata yakni “jaya” yang berarti menang, berhasil atau berjaya sedangkan "baya" berarti beboyo atau suatu kekacauan keadaan yang membahayakan atau dapat pula diartikan ebagai permasalahan. Maka didalam Serat Jangka Jayabaya ini menjadikan Jayabaya sebagai tokoh entral yang berhasil keluar dari bahaya yakni melalui wejangannya yang berbentuk jangka jaman yang berasal dari eksplorasi spiritual melalui gurunya Maulana Samsujen.

Sebuah konsep ratu adil, atau heru cakra merupakan sebuah esensi tatkala simbol kesejahteraan diharapkan sebagai resolusi suatu ketimpangan sosial yang ada. Sebuah pola fikir berdasarkan ramalan merupakan perwujudan dari mentalitas masyarakat jawa tradisional. Namun ketimpangan yang tampak ialah bahwa Sang Maharaja Sri Aji Jayabaya merupakan seorang pencipta dari ramalan tersebut. Jika kita tinjau lebih jauh lagi, sumber ramalan jayabaya merupakan kitab musarar, seperti tampak pada pembukaan isi serat Jayabaya. Hal ini merujuk pada kitab Musarar karya Sunan Giri III yang ditulis pada tahun $1618 M$. Sehingga sumber ini sebenarnya berada pada masa Sultan Agung Mataram. Kitab Jangka Jayabaya tertua dan otentik adalah karangan Pangeran Wijil I atau disebut dengan Pangeran Kadilangu II, yang dikarang pada tahun 1741-1743 M (Soewarno, 2004). Dalam konten isinya serat jayabaya merupakan sebuah sinkretisme islam kejawen. Hal ini tampak pada akulturasi budaya pada bagian pembuka, ketika diceritakan Sang Prabu Jayabaya bertemu dengan gurunya Maulana Ali Samsudin. Maka dapat diketahui dari hal tersebut bahwa sejatinya agama islam memiliki toleransi yang besar antar 
sesama. Yang mengajarkan nilai-nilai kebaikan dan kemanusiaan. Lahirnya Serat Jangka Jayabaya tidak terlepas dari pengaruh penjajahan bangsa barat di Indonesia yang dimulai dari jatuhnya kesultanan mataram ditangan VOC.

\section{Serat Jangka Jayabaya sebagai respon pujangga terhadap ketimpangan sosial}

Selama abad 18, VOC atau Vereenigde Oost-Indische dengan pasti telah menanamkan pengaruhnya dibidang ekonomi dan politik di Jawa. Sebagai sebuah kongsi dagang milik Belanda, VOC memulai hegemoni terhadap perdagangan di kerajaan-kerajaan Nusantara ditandai dengan adanya pemberikan kewenangan oleh pemerintah Belanda untuk berbentuk Hak Oktrooi VOC. Disinilah kemudian terjadi pergeseran pola penaklukan VOC kemudian mulai menanamkan pengaruh kolonialisme di Nusantara. Eksistensi VOC dalam perdagangan Asia telah ada sebagai kekuatan utama sejak awal abad ke-16, yang kemudian mengembangkan minat dalam campur urusan politik pribumi di kerajaan Jawa demi meningkatkan kekuasaan dan ekonomi pada abad 18. Dinamika perkembangan kerajaan-kerajaan jawa memiliki pasang surut oleh permasalahan intern dan ekstern. Figur pemimpin dalam setiap generasi menentukan bagaimana relasi yang terjalin dengan Belanda.
Kebesaran Mataram Islam
dibawah kepemimpinan Sultan Agung
yang dengan tegas memerangi intervensi
VOC dalam berbagai politik maupun
perdagangan. Kegigihan Sultan Agung
dalam mengusir VOC nampaknya tak
diwarisi oleh para penerusnya. Masa pemerintahan Amangkurat I memberikan gambaran instabilitas politik dengan munculnya berbagai pemberontakan. Dalam hal ini sikap Amangkurat I kurang bijaksanaa dalam melakukan kontrol serta perbaikan kekacauan yang terjadi, ia lebih condong dalam berbagai upaya mempertahankan dengan melenyapkan orang-orang yang mengancam kekuasaan. Hal yang demikian menjadikan Amangkurat lebih memilih jalan pintas dengan menjalin relasi dengan VOC sebagai dukungan. Yang dibuktikan oleh adanya perjanjian dimana Mataram harus mengakui secara politik adanya kekuasaan VOC di Batavia yang disusul dengan diterimanya utusan VOC setiap tahun ke Mataram. Adanya campur tangan politik VOC terhadap kerajaan Mataram Sejak pemerintahan Amangkurat I sampai dengan Amangkurat II dan seterusnya hingga erjanjian Giyanti merupakan implikasi bentuk kerjasama yang telah ditandatangai sebelumnya.

Sebuah konsep penting yang dikenal oleh bangsa Indonesia melalui penjajahan bangsa Barat adalah dikenalnya modernisasi. Modernasisasi 
Hindia Belanda dalam abad 18-19 merujuk pada upaya mendekonstruksi tananan sosial politik jawa sesuai dengan tatanan asal Negeri Belanda. Asumsi ini berdasar kepada superioritas budaya bangsa barat dalam menanamkan kekuasaan dan meraup keuntungan sebesar-besarnya didaerah jajahan, memili konstruksi budaya yang jauh berbeda dengan negeri jajahan. Dalam tatanan kelas sosial Belanda memberadabkan kaum pribumi dengan memperkenalkan pakaian modern, hal ini kemudian tampak hingga lingkungan keraton. Salah satunya adalah penggunaan beskap, dan slop. Di bidang pendidikan kemudian muncul berbagai sekolah modern, yang terbagi atas stratifikasi sosial kolonial. Sedangkan dalam politik, Konsep birokrasi tradisional jawa yang memahami keraton sebgai pusat pemerintahan, kesenian, perekonomian, tatanilai/hukum, tuntunan hidup/pendidikan, dan keagamaan dan representasi kosmologi jawa terjadi perubahan yang fundamental. Belanda membongkar hubungan sosial masyarakat tradisional jawa khususnya kaum priyagung (aristokrat) dengan kaum wong cilik (proletar) sebagai hubungan patron clien manunggaling kawulo gusti menjadi struktur birokrasi rasional antara penguasa dan rakyat biasa (Purwasito, 2017, hal. 145-151). Selain itu Belanda melakukan dualisme birokrasi yang terkesan memiliki unsur diskriminatif antara pihak yang dijajah dan yang menjajah. Penguasaan seluruh daerah mancanegara diiringi pembentukan Binnenlandsbestuur dan Inslandsbestur ini sangat merugikan kerajaan-kerajaan jawa karena memutus rantai kesetiaan Bupati kepada Raja (Joebagio, 2017). Bahkan pergeseran itu tampak ketika berbagai ritual yang dianggap sebagai legitimasi kekuasaan raja yang dipoleh melalui wahyu kedhaton, telah tergeser dengan pentingnya pengakuan pemerintah kolonial didalam setiap urusan politik keraton. Bahkan pengawasan juga dilakukan oleh pemerintahan kolonial terhadap berbagai tulisan pujangga keraton yang dianggap mengancam. Permasalahan dalam lingkup intern semakin pelik terkait kedekatan raja dengan pemerintah kolonial seolah menjadi alat dalam mengontrol masyarakat. Bahkan dalam budaya, para priyagung telah terkontaminasi berbagai budaya barat seperti dari cara berpakaian, dan mengenal berbagai hedonisme barat.

\section{Diskurus Ratu adil sebagai resistensi masyarakat terhadap kolonialisme sebagai benih nasionalisme \\ Penyimpangan sosial selalu terjadi sepanjang waktu. Dalam menyikapi hal ini diperlukan sebuah pengendalian sosial. Dalam serat jangka jayabaya khususnya pembabakan zaman}


kalabendu dijelaskan bahwa berbagai penyimpangan memerlukan sebuah pengendalian sosial yang kemudian disimbolkan akan datangnya seorang "heru cakra" atau secara harfiah simbolisme ratu adil, keadilan, kesejateraan, pembebasan dan perdamaian. Kontrol sosial dalam hal ini mengarah kepada berbagai upaya yang digunakan dalam mengembalikan keadaan menyimpang ke situasi yang ideal semula (Setiadi \& Kolip, 2010, hal. 146-147). Efektifitas kontrol sosial tampak pada akhir serat jangka jayabaya ini. Menurut keterangan wawancara dengan seorang pakar sastra jawa mengungkapkan bahwa ciri khas dari serat atau berbagai tulisan karanga Ranggawarsita selalu menampilkan sebuah permasalahan yang dilengkapi oleh penyelesaiannya. Maka penggunaan serat ini sangat relevan diangkat dalam pembelajaran sejarah. dalam setiap pembelajaran sejarah harus memiliki misi yang akan diangkat. Misi merupakan tujuan, kemana pembelajaran sejarah akan diarahkan. Maka pembelajaran sejarah dengan serat jangka jayabaya memberikan peran aktual dalam mengangkat permasalahan kontemporer kekinian dan termutakhir.

Serat atau manuskrip merupakan salah satu sumber pembelajaran sejarah sejarah berupa dokumen. Serat sebagai bentuk tindakan sosial pujangga dengan beberapa maksud tertentu baik secara sosial, budaya, politis, maupun ekonomi. Maka peran pujangga dalam konteks keraton adalah sebagai seseorang yang harus mengagungkan rajanya dimana legitimasi politik merupakan sarana yang sah agar sorang raja diakui menjadi pembesar dengan beberapa kriteria tertentu termasuk dalam hal spiritual. Namun dalam beberapa situasi tertentu, perubahan pola tindakan seorang pujangga menjadi sebuah keniscayaan tatkala dihadapkan dalam suatu kenyataan sosial yang ada. Seorang pujangga sebagai abdi dalem harus mampu menempatkan diri dan menjalankan tugas serta kewajibannya baik terhadap atasan, sesama maupun bawahannya. Selain itu sebagai penulis, ia harus mampu melihat mana yang semu dan mana yang ril (Purwadi, 2005, hal. 79). Ranggawarsita menangkap adanya kesenjangan antara realitas sosial dengan norma dan etika sosial yang berlaku. Maka dalam hal ini, tulisan didalam serat dapat diartikan sebagai eksplanasi seorang cendekiawan yang kritis dalam menangkap gejolak sosial. penguasa keraton yang telah ditelanjangi kekuasaannya oleh pemerintah belanda merupakan sumber timbulnya sentimen dan jiwa nasionalisme. Maka penyesuaian Ranggawarsita yang bergaul dengan tokoh-tokoh pemerintah dan pejabat Belanda menemukan kecacatan etika dan moral sehingga ia menamainya dengan 
zaman edan, atau zaman kalabendu (Simuh, 1988, hal. 262 -263)

Arogansi Belanda terhadap cara pandangnya terhadap pribumi nampaknya memberikan dampak yang signifikan terhadap keberterimaan perubahan diberbagai bidang. Terdapat dua pola yang berbeda antara respon aristokrat jawa dengan golongan bawah. Golongan penguasa cenderung memilih untuk disibukkan dengan menjaga eksistensi kekuasaannya yang bersifat feodal ditengah revolusi birokrasi dan berbagai sistem pemerintahan sedangkan pada masyarakat kelompok bawah yang merasakan berbagai kerugian akibat sistem kolonialisme yang memberatkan, baik berupa pajak, kerja paksa, sistem pertanian, dan berbagai eksploitasi Belanda memilih melakukan penolakan melalui gerakan-gerakan radikalisme berideologi mistis-religius, yakni dengan mengangkat konsep Ratu Adil dalam menghimpun solidaritas sebagai resistensi atas ketidakadilan. Sebenarnya ideologi perang suci merupakan salah satu strategi paling berhasil dalam menghimpun masa berdasar ikatan emosionalitas. Hal ini dapat kita lihat dasyatnya perang salib dalam memanfaatkan agama sebagai pengabsahan ideologi barat dan timur menanamkan konsep perang suci atau jihad fissabillilah sebagai motivasi spiritual muslim dalam melakukan gempuran kepada umat nasrani.
Resistensi jihad memberikan garis tegas dalam memberikan label pihak-pihak yang tidak sesuai sebagai kaum kafir yang harus diperangi. Penguatan gerakan ini menggunakan ritual atau magis sebagai alat legitimasi. Sebagaimana pengetahuan masyarakat jawa terhadap akumulasi ngelmu titen menjadi dasar penguat terhadap berbagai ramalan akan datangnya Ratu Adil.

Diskursus Ratu Adil yang demikian merupakan cara berfikir historis yang sebenarnya telah dimiliki setiap individu dalam proses kehidupan. Dianatara berbagai guncangan dan perubahan sosial seseorang akan memandang masa lalu sebagai pijakan dalam menentukan sikap dimasa depan. Maka gerakan resistensi ini menggunakan nilai-nilai lokal genius yang secara empiris dipahami melalui kebenaran yang universal. Walaupun belum diketahui pasti tentang siapakah pengarang serat Jangka Jayabaya yang sebenarnya, apakah memang kemampuan Raja Jayabaya atau memang sengaja diangkat sebagai figur dalam karya sastra tetapi eksistensi konsep keadilan seperti dalam serat Jangka Jayabaya datangnya Heru Cakra, merupakan sang juru selamat / misianis yang selalu dinantikan oleh rakyat tatkala dihadapkan dengan dilematis akibat realitas yang tak selalu sejalan dengan idealisme sebelumnya.

Konsep Ratu Adil demikian memiliki signifikansi terhadap berbagai 
protes sosial atau pergantian kekuasaan ini selalu dimunculkan kembali dalam berbagai fase dalam Sejarah hingga era kontemporer. Konsep Ratu Adil atau seorang juru selamat kian mendapat perhatian dan meningkat popularitasnya ketka Rng Ranggawarsita seorang pujangga keraton, membuat diskursus mengenai berbagai kekacauan dengan sebutan "zaman edan”. Adapun didalam zaman edan sesungguhnya diidamkan adanya seorang pemimpin yang adil "ratu adil" sebagai sang pembebas. Bahkan popularitas Jangka Jayabaya/ ramalan Jayabaya dikalangan masyarakat jawa secara umum tengah mempengaruhi perkembangan teks dari serat jangka jayabaya itu sendiri. Perkembangan isi jangka kemudian disesuaikan oleh berbagai situasi yang esensinya merujuk pada ketimpangan sosial di masayarakat. Salah satu bukti besarnya pengaruh diskursus ratu adil sebagai resistensi melawan kolonialisme ditunjukkan oleh Pangeran Diponegoro yang terkenal dengan sebutan perang jawa. Segala bentuk kolonialisme ibarat arang disetiap sudut yang menunggu percikan api untuk dapat membara. Hal ini esensinya merupakan salah satu cikal bakal lahirnya nasionalisme pada pergerakan nasional yang cenderung berazazkan agama dan kepercayaan. Pangeran Diponegoro dengan pengetahuannya tentang Islam kemudian mengobarkan semangat perang suci melawan kolonialisme. Ideologi pengabsahan pergerakan mengasimilasi konsep jihad dan berbagai strategi perang Islam dengan konsep ratu adil sesuai dengan Jangka Jayabaya dalam mengikat kepercayaan anggota.

Dalam perkembangan selanjutnya, adapun kaum nasionalis juga memanfaatkan ramalan dan mitos sebagai alat legitimasi perjuangan resistensi mereka terhadap kolonial dengan mempopulerkan ramalan Jayabaya sebagai ideologi pengabsahan (Purwasito, 2017, hal. 163). Bahkan kekalahan Belanda yang berganti pada pemantaban kekuasaan Jepang di Indonesia dianggap sebagai sebuah pembebasan terhadap situasi kekacauan yang selama ini terjadi. Menangkap hal tersebut, Jepang memanfaatkan situasi dengan membangun diskursus tentang Ratu Adil pada awal penguasaan dengan pamflet-pamflet yang berisi ramalan Jayabaya yang isinya mengajak sultan Yogyakarta dan susuhan Surakarta membantu Jepang Sang Pembebas rakyat. Konsep Ratu Adil masa-masa setelah kemerdekaan masih memiliki pengaruh terhadap mentalitas masyarakat jawa dalam merespon keguncangan sosial. Maka seberapa besar guncangan yang terjadi, berimplikasi terhadap besarnya harapan terhadap datangnya Ratu Adil. Momen seperti inilah yang kemudian ditangkap oleh partai politik dalam mengambil figur 
pemimpin yang memiliki popularitas kedekatan dengan wong cilik. Sebagai contoh berakhirnya kekuasaan Susilo Bambang Yudoyono, dengan berbagai kasus yang menyeret partai Demokrat dalam hal KKN, digantikan dengan naiknya figur Jokowi sebagai Presiden dari partai PDIP. Yang sangat menarik adalah, dialog masyarakat desa, para ulama bahkan wong ngerti (sebutan lain dari orang jawa yang memiliki keahlian nujum dan spiritual) mengungkapkan bahwa Jokowi adalah seorang Ratu Adil sebagai pembawa kesejahteraan. Yang membebaskan rakyat kecil dari berbagai kesusahan. Maka, sebuah pola pikir terhadap Ratu Adil sejatinya memiliki relefansi ketika hal tersebut dibuktikan secara empiris kebenarannya.

\section{PENUTUP}

\section{Simpulan}

1. Nasionalisme abad 18 lahir dari adanya kesatuan dan persatuan dengan ideologi ratu adil yang didukung oleh aristokrat keraton sebagai penggerak masa.

2. Secara ontologis serat Jangka Jayabaya gubahan ranggawarsita merupakan sebuah karya sastra abad 18 yang didalamnya menceritakan Jayabaya sebagai tokoh sentral yang berhasil keluar dari bahaya yakni melalui wejangannya yang berbentuk jangka jaman yang berasal dari eksplorasi spiritual melalui gurunya Maulana Samsujen.

3. Secara epistemologis Serat Jangka Jayabaya diusun melalui kegundahan pujangga keraton dalam merespon berbagai ketimpangan sosial yang terjadi di dalam masyarakat. Sehingga tanggung jawab sebagai seorang pujangga bukan hanya terhadap sultan melainkan juga masyarakat luas.

4. Secara aksiologis Serat Jangka Jayabaya merupakan sebuah respon penolakan terhadap ketimpangan sosial akibat penjajahan. Konep ratu Adil dan sosok herucakra merupakan sebuah simbolisme pembebasan terhadap kekacauan yang sedang terjadi. Popularitas Serat Jangka Jayabaya semakin meluas tatkala seorang Ranggawarsita sebagai pujangga keraton mengangkat konsep zaman edan dalam serat Kalathida yang ia adopsi berdasarkan ramalan Jangka Jayabaya. Namun popularitas ini justru semakin meningkat tatkala zaman pergerakan kemerdekaan dimana para pejuang membutuhkan sebuah pemersatu sebelum dikenalnya nasionalisme. Sebuah konsep yang kemudian diambil ialah nasionalime keagamaan dengan diskursus ratu adil dalam resistensi melawan penjajahan.

Sehingga kesimpulan yang dapat diambil ialah tingkat popularitas serat Jangka Jayabaya dipengaruhi oleh faktor tingginya guncangan/kekacauan dalam 
masyarakat. Adapun sikap masyarakat terhadap ketidakstabilan sosial adalah 2 macam. Yang pertama adalah menengok kebelakang, yakni belajar dari nilai-nilai sejarah dan yang kedua adalah melihat kedepan, dengan mereflekikan nilai-nilai di masa lalu.

\section{Saran}

Kita perlu meninjau berbagai bentuk sumber sejarah tanpa harus mengesampingkan keontetikan naskah. Karena pada dasarnya historiografi tradisional Indonesia bukan hal yang tabu untuk dikupas lebih lanjut melalui metodologi sejarah kontemporer. Metode atau pendekatan dalam penulian sejarah sangat mempengaruhi nilai dari sebuah narasi sejarah. Melalui metode intertekstual yang membandingkan relasi antar karya sastra, bukan tidak mungkin mengangkat sastra sebagai suatu sumber sejarah yang ditinjau dari sosio kultural situasi kepengarangan pada masanya.

\section{DAFTAR PUSTAKA}

Hidayat, B. (2016). Aplikasi Penulisan Sejarah pada Mata Kuliah Sejarah Sosial. Historia Volumen 4 Nomor $1,12$.

Joebagio, H. (2017). Islam dan Kebangsaan di Keraton Surakarta. Sukoharjo: Dio Media dan CHERS.

Kuswono. (2017). Pengembangan Modul Sejarah Pergerakan Indonesia Terintegrasi Nilai Karakter Religius. Historia Vol.5 No.1, 3346.
Purwadi. (2005). Mistik Kejawen Pujangga Ranggawarsita. Yogyakarta: Media Abadi .

Purwasito, A. (2017). Imageri India. Surakarta: UNS Press.

Sasmita, G. G. (2017). Antara Agama dan Sinkretisme. Sejarah Lokal: Tantangan dan Maa Depan (pp. 53-62). Malang: Fakulta Ilmu Soial Universitas Negeri Malang.

Setiadi, E. M., \& Kolip, U. (2010). Pengantar Sosiologi Pemahaman Fakta dan Gejala Sosial: Teori, Aplikasi dan Pemecahannya. Jakarta: Kencana Prenada Grou.

Simuh. (1988). Mistik Islam Kejawen Raden Ngabehi Ranggawarsita Suatu Studi Terhadap Serat Wirid Hidayat Jati . Jakarta: UI Press.

Soewarno, H. (2004). Ramalan Joyoboyo versi Sabdopalon. Kediri.

Sondarika, W. (2017). Peranan Wanita dalam Perjuangan Kemerdekaan Indonesia Masa Pendudukan Jepang. Historia Vol.5 No 2, 207217.

Susilo, A. (2018). Perjuangan Jendral Soedirman dalam Mempertahankan Indonesia (19451950). Historia Vol. 6 No.1, 5768. 